\title{
Class II malocclusion treatment using high-pull headgear with a splint: A systematic review
}

Helder B. Jacob¹, Peter H. Buschang², Ary dos Santos-Pinto ${ }^{3}$

Objective: To systematically review the scientific evidence pertaining to the effectiveness of high-pull headgear in growing Class II subjects. Methods: A literature survey was performed by electronic database search. The survey covered the period from January 1966 to December 2008 and used Medical Subject Headings (MeSH). Articles were initially selected based on their titles and abstracts; the full articles were then retrieved. The inclusion criteria included growing subjects between 8 to 15 years of age, Class II malocclusion treatment with high-pull headgear, and a control group with Class II malocclusion. References from selected articles were hand-searched for additional publications. Selected studies were evaluated methodologically. Results: Four articles were selected; none were randomized controlled trials. All of the articles clearly formulated their objectives and used appropriate measures. The studies showed that high-pull headgear treatment improves skeletal and dental relationship, distal displacement of the maxilla, vertical eruption control and upper molars distalization. One of the studies showed a slight clockwise rotation of the palatal plane; the others showed no significant treatment effect. The mandible was not affected by the treatment. Conclusion: While there is still a lack of strong evidence demonstrating the effects of high-pull headgear with a splint, other studies indicate that the AP relations improve due to distalization of the maxilla and upper molars, with little or no treatment effects in the mandible. Greater attention to the design should be given to improve the quality of such trials.

Keywords: Orthodontics. Angle Class II malocclusion. Treatment results.

Objetivo: fazer uma revisão sistemática das evidências científicas mostrando a efetividade do aparelho extrabucal com cobertura oclusal associado à tração alta em pacientes com má oclusão Classe II em crescimento. Métodos: um levantamento na literatura foi realizado por meio de pesquisa em bancos de dados eletrônicos, cobrindo o período de janeiro de 1966 a dezembro de 2008, utilizando o Medical Subject Headings (MeSH). Inicialmente, a seleção foi baseada em títulos e resumos; após essa etapa, os artigos potencialmente selecionados foram integralmente observados. Os critérios de inclusão apresentaram pacientes em crescimento, entre 8 e 15 anos de idade, má oclusão de Classe II tratada com aparelhos extrabucais com cobertura oclusal e tração alta, tendo grupo controle também com má oclusão de Classe II. Os estudos selecionados foram avaliados metodologicamente. Resultados: quatro artigos foram selecionados. Nenhum foi estudo controlado randomizado. Os artigos claramente formularam seus objetivos e usaram medidas apropriadas. Os estudos mostraram que houve melhora nas relações esqueléticas e dentárias, deslocamento da maxila distalmente, controle da erupção vertical e distalização dos molares superiores. Um estudo mostrou uma suave inclinação horária do plano palatino. A mandíbula não foi afetada. Conclusão: embora exista falta de forte evidência mostrando os efeitos do aparelho extrabucal com cobertura oclusal, estudos realizados indicaram que a relação anteroposterior melhorou devido à distalização da maxila e dos molares superiores, com pequeno ou nenhum efeito na mandíbula. Uma maior preocupação quanto ao desenho deveria ser dada para melhorar a qualidade de pesquisas com esse tipo de abordagem.

Palavras-chave: Ortodontia. Má oclusão de Angle Classe II. Resultado de tratamento.

${ }^{1} \mathrm{PhD}$ in Orthodontics, Araraquara Dental School/São Paulo State UniversityUNESP, Araraquara, SP, Brazil. Post-doc in Orthodontics, Texas A\&M Health Science Center.

${ }^{2}$ Professor, Baylor College of Dentistry, Texas A\&M Health Science Center.

${ }^{3}$ Professor, Department of Orthodontics, Araraquara Dental School, São Paulo State University-UNESP, Araraquara, SP, Brazil

Submitted: September 15, 2010 - Revised and accepted: October 22, 2011
How to cite this article: Jacob HB, Buschang PH, Santos-Pinto A. Class II malocclusion treatment using high-pull headgear with a splint: A systematic review. Dental Press J Orthod. 2013 Mar-Apr; 18(2):21.el-7.

Contact address: Helder Baldi Jacob

3302 Gaston Ave - Baylor College of Dentistry

Department of Orthodontics

75206 Dallas/TX - USA

E-mail: hjacob@bcd.tamhsc.edu 


\section{INTRODUCTION}

Class II malocclusion can be dental and/or skeletal, involving mandibular deficiency, maxillary excess, or a combination of both. ${ }^{1,2}$ Hyperdivergent patients with Class II malocclusion typically present with numerous three-dimensional skeletal and dental problems. ${ }^{3}$ They exhibit retrognathic mandibles, ${ }^{4}$ long anterior facial heights, ${ }^{3}$ large mandibular plane angle, ${ }^{4}$ large gonial angles,${ }^{3}$ and greater than average anterior facial height ratio. ${ }^{5,6,7}$ Dentally, they often present with open bite ${ }^{9}$ and overerupted incisors and molars in both arches. ${ }^{3}$

Orthodontists have attempted to address the vertical dimension of growing hyperdivergent patients in various ways (e.g. bite-blocks, extraction therapy, vertical-pull chin, etc.), with high-pull headgear being perhaps the most common approach. The use of extraoral high-pull forces to modify maxilla growth has a long history. The type of extraoral traction device, as well as the magnitude of force applied and the direction of pull, have been shown to be important considerations. ${ }^{8,9}$ High-pull headgear has been shown to modify maxillary growth; ${ }^{10}$ when attached to a splint directs maxillary growth towards a more posterosuperior direction. ${ }^{11,12}$ To date, the treatment effects of high-pull headgear have not been systematically studied.

The purpose of this study was to systematically review clinical studies that have evaluated how high-pull headgear treatment with a splint affects growing Class II hyperdivergent patients. The review will foccused on:

»Changes in the amount and direction of skeletal growth.

»Control of maxillary and mandibular molar eruption.

» Improvements of the vertical and AP skeletal relationship.

\section{MATERIAL AND METHODS}

In order to identify all studies that examined treatment with high-pull headgear in patients with Class II malocclusion, a literature survey was performed using PubMed and Scopus databases. The survey covered the period from January 1966 to December 2008. Using the Medical Subject Heading (MeSH) term "orthodontics", crossed with the MeSH terms "malocclusion, Class II malocclusion" and "extraoral traction appliance", a total of 442 studies were identified. Only randomized controlled trials (RCTs) or non-randomized controlled trials (using untreated Class II hyperdivergent patients as controls) were included (Table 1). At the first view no distinction was made between high-pull headgear with a maxillary splint or banded molars. The reference list of each article was hand-searched for additional relevant publications that may have been missed in the database searches.

Following the recommendations by Petrén et al, ${ }^{13}$ the articles were described based on the following: study design, sample size, male and female distribution, mean age of groups, type of orthodontic treatment, treatment duration, success, and authors' conclusion (Table 2).

To document the methodological soundness of each article, a modified version of the quality evaluation described by Antczak et a $1^{14,15}$ was used (Table 3). The adequacy of sample was determined based on post-hoc power analyses of the primary variable used in each study to evaluate the AP treatment effects on the maxilla. The total quality score was based on assigning 1 point for each "Yes" in the Table, zero points for each "No", and 1 point for each controlled clinical trial (CCT). Prospective and retrospective studies were given one and zero points, respectively. The total number of points possible was 10 .

Modified pitchfork diagrams were used to summarize the rotations, displacements and tooth movements associated with the high-pull headgear treatments. Rotations were based on the angular changes of the palatal and mandibular planes. The horizontal and vertical displacements of the maxilla and mandible were based on cranial base superimpositions. Tooth migration and eruption was based on maxillary and mandibular superimpositions. Estimates were based on averages of the four studies that provided tooth movements based on maxillary and mandibular superimpositions. 
Table 1 - Inclusion and exclusion criteria used to select the articles.

\begin{tabular}{ll}
\hline Inclusion criteria & Exclusion criteria \\
- Meta-analyses, randomized clinical trials, prospective and retrospective studies & - Case reports, case series, descriptive studies, opinion articles or abstracts \\
- Articles published from January 1966 and December 2008 & - Studies with casts \\
- Studies with Class II malocclusion & - Not human studies or laboratorial studies \\
- Studies with growing patients 8-15 years & - Adjunctive treatments \\
- Studies with extraoral high-pull headgear, using maxillary splints or banded & - Full or partially banded appliances \\
- molars & - Subjects with TMJ diseases \\
\hline
\end{tabular}

Table 2 - Summarized data of the studies included in the review.

\begin{tabular}{|c|c|c|c|c|c|c|c|c|}
\hline $\begin{array}{l}\text { Authors } \\
\text { and year }\end{array}$ & $\begin{array}{l}\text { Study } \\
\text { design }\end{array}$ & $\begin{array}{l}\text { Sample } \\
\text { size }\end{array}$ & $\begin{array}{l}\text { Male } \\
(\%)\end{array}$ & Age & $\begin{array}{l}\text { Orthodontic } \\
\text { treatment }\end{array}$ & $\begin{array}{l}\text { Treatment } \\
\text { duration }\end{array}$ & Success & Authors' conclusion \\
\hline $\begin{array}{l}\text { Caldwell } \\
\text { et al }{ }^{12} \\
(1984)\end{array}$ & ССТ & $\begin{array}{l}47 \mathrm{HG} \\
52 \mathrm{CG}\end{array}$ & $\begin{array}{l}\text { HG: } 45 \% \\
\text { CG: } 52 \%\end{array}$ & $\begin{array}{c}H G: \\
M=10.23(y) \\
F=10.19(y) \\
C G: \\
M=10.36(y) \\
F=10.21(y)\end{array}$ & $\begin{array}{l}\text { Maxillary } \\
\text { splint } \\
\text { appliance }\end{array}$ & $\begin{array}{c}\text { Between } \\
4 \text { and } 20(\mathrm{~m})\end{array}$ & $\begin{array}{c}\text { Not declared } \\
\text { (100\% - implicit) }\end{array}$ & $\begin{array}{l}\text { The maxillary dentition was both } \\
\text { tipped and displaced distally, and } \\
\text { downward development was } \\
\text { inhibited or even slightly reversed }\end{array}$ \\
\hline $\begin{array}{l}\text { Martins } \\
\text { et al }{ }^{18} \\
(2008)\end{array}$ & СCT & $\begin{array}{l}17 \mathrm{HG} \\
17 \mathrm{CG}\end{array}$ & $\begin{array}{l}\text { HG: } 24 \% \\
\text { CG: } 47 \%\end{array}$ & $\begin{array}{l}\text { HG: } \\
8.61(y) \\
\text { CG: } \\
8.9(y)\end{array}$ & $\begin{array}{l}\text { Maxillary } \\
\text { splint } \\
\text { appliance }\end{array}$ & $\begin{array}{l}\text { HG: } \\
1.70(y) \\
\text { CG: } \\
1.40(y)\end{array}$ & $\begin{array}{c}\text { Not declared } \\
\text { (100\% - implicit) }\end{array}$ & $\begin{array}{c}\text { The HG corrected the Class II } \\
\text { primarily by dentoalveolar } \\
\text { changes }\end{array}$ \\
\hline $\begin{array}{l}\text { Orton } \\
\text { et } \mathrm{al}^{19} \\
(1992)\end{array}$ & ССТ & $\begin{array}{l}26 \mathrm{HG} \\
26 \mathrm{CG}\end{array}$ & $\begin{array}{l}\text { HG: } 42 \% \\
\text { CG: } 42 \%\end{array}$ & $\begin{array}{l}\text { HG: } \\
11.4(y) \\
\text { CG: } \\
11(y)\end{array}$ & $\begin{array}{l}\text { Maxillary } \\
\text { splint } \\
\text { appliance }\end{array}$ & $\begin{array}{l}\text { HG: } \\
1.1(y) \\
C G: \\
1.7(y)\end{array}$ & $\begin{array}{c}\text { Not declared } \\
\text { (100\% - implicit) }\end{array}$ & $\begin{array}{l}\text { Slight maxillary restraint in both } \\
\text { sagittal and vertical planes was } \\
\text { obtained showing that principal } \\
\text { effect was in the maxillary teeth }\end{array}$ \\
\hline $\begin{array}{c}\text { Üner, Yücel- } \\
\text { Eroğlu²0 } \\
\text { (1996) }\end{array}$ & ССТ & $\begin{array}{l}13 \mathrm{HG} \\
13 \mathrm{CG}\end{array}$ & $\begin{array}{l}\text { HG: } 46 \% \\
\text { CG: } 46 \%\end{array}$ & $\begin{array}{l}\text { HG: } \\
10.76 y \\
\text { CG: } \\
10.39(y)\end{array}$ & $\begin{array}{c}\text { Maxillary } \\
\text { splint } \\
\text { appliance }\end{array}$ & $\begin{array}{c}\text { HG: } \\
11.00(\mathrm{~m}) \\
\mathrm{GC}: \\
11.31(\mathrm{~m})\end{array}$ & $84 \%$ & $\begin{array}{l}\text { The HG revealed that the } \\
\text { splint had both orthopedic and } \\
\text { orthodontic effects on the growth } \\
\text { pattern of the dentoskeletal } \\
\text { structures }\end{array}$ \\
\hline
\end{tabular}

Table 3 - Quality evaluation of the 6 selected studies (CCT: control clinical trial)

\begin{tabular}{|c|c|c|c|c|c|c|c|c|c|c|}
\hline $\begin{array}{l}\text { Authors } \\
\text { and year }\end{array}$ & $\begin{array}{c}\text { Objective } \\
\text { clearly } \\
\text { formulated }\end{array}$ & $\begin{array}{l}\text { Study } \\
\text { design }\end{array}$ & $\begin{array}{l}\text { Adequacy } \\
\text { of selection } \\
\text { description }\end{array}$ & $\begin{array}{l}\text { Adequate } \\
\text { sample } \\
\text { size }\end{array}$ & $\begin{array}{c}\text { Appropriate } \\
\text { measurement } \\
\text { method }\end{array}$ & $\begin{array}{c}\text { Retrospective } \\
\text { / prospective } \\
\text { study }\end{array}$ & $\begin{array}{c}\text { Appropriate } \\
\text { statistical } \\
\text { analysis }\end{array}$ & $\begin{array}{c}\text { Description of } \\
\text { method error } \\
\text { analysis }\end{array}$ & $\begin{array}{c}\text { Blind } \\
\text { measurement }\end{array}$ & $\begin{array}{c}\text { Quality } \\
\text { score I } \\
\text { total }\end{array}$ \\
\hline $\begin{array}{c}\text { Caldwell et a }{ }^{12} \\
\text { (1984) }\end{array}$ & Yes & CCT & No & Yes & Yes & Retrospective & No & No & No & 4 \\
\hline $\begin{array}{c}\text { Martins et } a^{18} \\
\text { (2008) }\end{array}$ & Yes & ССТ & Yes & Yes & Yes & Prospective & Yes & Yes & No & 7 \\
\hline $\begin{array}{l}\text { Orton et al }{ }^{19} \\
\text { (1992) }\end{array}$ & Yes & CCT & Yes & Yes & Yes & Retrospective & Yes & No & No & 6 \\
\hline $\begin{array}{c}\text { Üner, } \\
\text { Yücel-Eroğlu²0 } \\
\text { (1996) }\end{array}$ & Yes & CCT & Yes & Yes & Yes & Retrospective & Yes & Yes & No & 7 \\
\hline
\end{tabular}




\section{RESULTS}

Based on the information provided in the titles and abstracts of the 442 articles identified, 17 of the studies were pre-selected (Fig 1). The main reasons for exclusion were: Different types of appliances used (e.g. high-pull headgear associated with functional appliance or bonded brackets), the direction of force application (cervical or combination traction), no cephalometric data provided, and case reports. Of the 17 studies identified, only 4 used untreated Class II control. ${ }^{12,18-20}$

Sample sizes of the treatment groups ranged from 13 to 47, with comparable numbers of controls ( $\mathrm{Ta}-$ ble 2). While the sex ratio ranged from 24 to $46 \%$ of males, none of the studies analyzed sex differences. Pretreatment ages and treatment durations ranged from 8.6 to 11.4 years and 4 to 20 months, respectively. All four selected studies compared maxillary orthopedic splint versus no treatment.

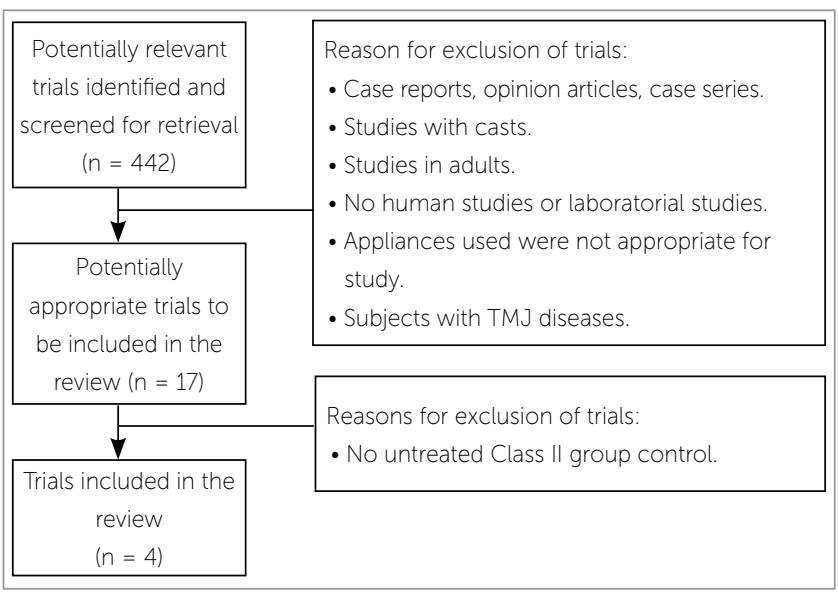

Figure 1 - Flow diagram summarizing literature search.

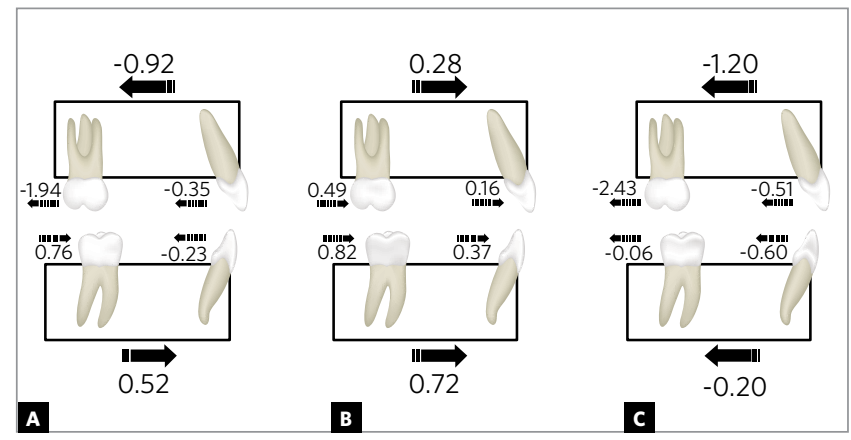

Figure 2 - Modified pitchforks of average horizontal $(\mathrm{mm})$ changes reported for (A) patient treated with headgear and (B) matched untreated controls, along with (C) differences between high-pull headgear and controls.
Three of the studies implied a 100\% success Class II correction; the Üner and Yücel-Eroğlu ${ }^{20}$ study reported an $84 \%$ success rate.

The quality evaluation scores of the four studies ranged from 4 to 7 (Table 2). None of the articles were RCT; all studies were controlled clinical trials. None of the articles blinded the measurement process. Only one of the studies was prospective and only two described the methods used for the error analysis. Three of the studies adequately described the selection of their subjects and three used appropriate statistical techniques. All of the articles clearly formulated their objectives and all used appropriate measures.

\section{Treatment effects produced by high-pull headgear}

Treatments consistently improved the AP skeletal relationships (with the ANB angle decreasing from 0.9 to 1.5 degrees and the Wits decreasing from 0.6 to $1.5 \mathrm{~mm}$ ), decreased overjet (2.6 to $6.5 \mathrm{~mm})$, and corrected the Class II malocclusions (Table 4).

\section{Maxillary treatment effects}

Although the studies used different criteria to measure the anteroposterior displacement, they all reported statistically significant posterior displacement of the maxilla (ranging from 0.1 to $0.5 \mathrm{~mm}$ ) for the treated group, versus anterior displacement for the untreated controls (Fig 2). Of the three studies that evaluated the palatal plane angle, just one study showed statistically significant clockwise rotation between the treated and control groups (Fig 3).

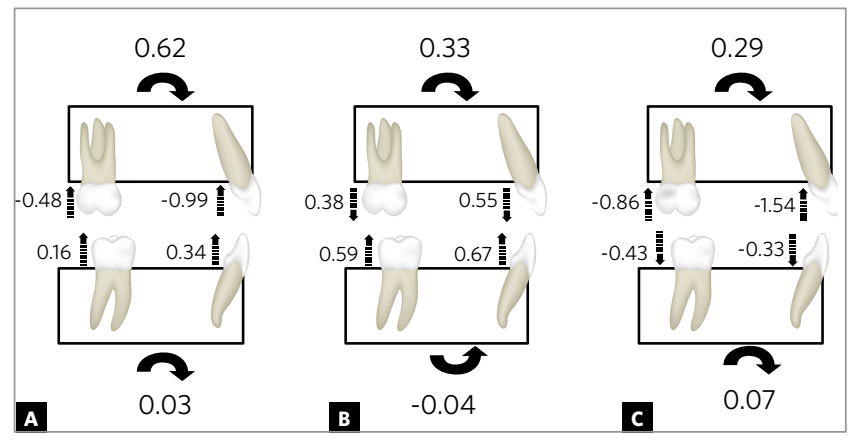

Figure 3 - Modified pitchforks of average vertical $(\mathrm{mm})$ and angular (degrees) changes reported for (A) patient treated with headgear and (B) matched untreated controls, along with (C) differences between high-pull headgear and controls. 
Table 4 - Treatment effects based on significant differences between patients and untreated controls.

\begin{tabular}{|c|c|c|c|c|c|}
\hline $\begin{array}{l}\text { Authors } \\
\text { and year }\end{array}$ & $\begin{array}{l}\text { Antero-posterior } \\
\text { relationships }\end{array}$ & $\begin{array}{c}\text { Skeletal-maxillary } \\
\text { changes }\end{array}$ & $\begin{array}{c}\text { Dental-maxillary } \\
\text { changes }\end{array}$ & $\begin{array}{c}\text { Skeletal-mandibular } \\
\text { changes }\end{array}$ & $\begin{array}{c}\text { Dental-mandibular } \\
\text { changes }\end{array}$ \\
\hline $\begin{array}{l}\text { Caldwell et a }{ }^{12} \\
\qquad(1984)\end{array}$ & $\begin{array}{l}\text { Decreased ANB; } \\
\text { decreased overjet }\end{array}$ & $\begin{array}{c}\text { Posterior displacement; } \\
\text { backward rotation of } \\
\text { palatal plane }\end{array}$ & $\begin{array}{l}\text { Distalized molars; } \\
\text { intruded molars; retroclined } \\
\text { incisor; intruded incisors }\end{array}$ & $\begin{array}{c}\text { Anterior displacement NS; } \\
\text { backward mandibular } \\
\text { rotation }\end{array}$ & $\begin{array}{l}\text { Mesialized molar NS; } \\
\text { extruded molar NS; } \\
\text { incisor retroclined }\end{array}$ \\
\hline $\begin{array}{l}\text { Martins et } \mathrm{a}^{18} \\
\text { (2008) }\end{array}$ & $\begin{array}{l}\text { Greater decreased } \\
\text { ANB and Wits than } \\
\text { expected }\end{array}$ & $\begin{array}{c}\text { Posterior displacement; } \\
\text { palatal plane angle NE }\end{array}$ & $\begin{array}{l}\text { Distalized molars; } \\
\text { intrusion NE; } \\
\text { retroclined incisors }\end{array}$ & $\begin{array}{c}\text { Anterior displacement NS; } \\
\text { mandibular rotation NS }\end{array}$ & $\begin{array}{c}\text { Mesialized molar NS; } \\
\text { incisor proclined NS; } \\
\text { vertical NE }\end{array}$ \\
\hline $\begin{array}{l}\text { Orton et al }{ }^{19} \\
\text { (1992) }\end{array}$ & $\begin{array}{l}\text { Reduction of ANB; } \\
\text { decreased overjet }\end{array}$ & $\begin{array}{c}\text { Posterior displacement; } \\
\text { backward rotation of the } \\
\text { palatal plane }\end{array}$ & $\begin{array}{l}\text { Distalized molars; intruded } \\
\text { molars; retroclined incisors; } \\
\text { intruded incisors }\end{array}$ & $\begin{array}{c}\text { Anterior displacement NS; } \\
\text { mandibular rotation NS }\end{array}$ & $\begin{array}{c}\text { Mesialized molar NS; } \\
\text { extruded molars; } \\
\text { incisor retroclined NS }\end{array}$ \\
\hline $\begin{array}{c}\text { Üner and } \\
\text { Yücel-Eroğlu²0 } \\
\text { (1996) }\end{array}$ & $\begin{array}{c}\text { Correction of Class II } \\
\text { molar relations; } \\
\text { decreased overjet }\end{array}$ & $\begin{array}{c}\text { Posterior displacement; } \\
\text { NS in palatal plane } \\
\text { rotation }\end{array}$ & $\begin{array}{l}\text { Distalized molars; molar } \\
\text { intrusion NS; proclined } \\
\text { incisors; intruded incisors }\end{array}$ & $\begin{array}{c}\text { Anterior displacement NS; } \\
\text { mandibular rotation NS }\end{array}$ & $\begin{array}{c}\text { Molar movements NS; } \\
\text { incisors retroclined }\end{array}$ \\
\hline
\end{tabular}

(NS=no significant group differences; NE= not evaluated).

All of the studies reported significant distalization of the maxillary molar (ranging between 0.5 and $3.3 \mathrm{~mm}$ ) and two showed maxillary molar intrusion (between 0.4 and $0.7 \mathrm{~mm}$ ). The control groups typically showed mesial drift and eruption of the maxillary molars (Figs 2 and 3 ). Three studies reported statistically significant retroclination (between 4.4 and 11.0 degrees) and intrusion of the maxillary incisors (between 0.2 and $2.1 \mathrm{~mm}$ ).

\section{Treatment effects on the mandible}

All four articles showed no treatment effect on the AP position of the mandible (Fig 2). All studies evaluated the mandibular plane rotation and reported no significant differences between the treated and control groups (Figs 2 and 3).

All studies reported similar amounts of mesial movement of the mandibular molars (ranging between $0.8 \mathrm{~mm}$ and $1.2 \mathrm{~mm}$ ) for the treated and control groups (Fig 2). Of the three studies that evaluated the vertical movements of the molars, all showed no treatment effects, but just one showed relative molar extrusion (Fig 3). Of the four articles that evaluated the incisors, three showed incisor retroclination (ranging from 0.2 to 1.9 degrees), and one showed incisor proclination (1.0 degree) with no significant difference between both groups.

\section{DISCUSSION}

The goal of orthopedic headgear treatment is to correct the dental malocclusion, normalize AP skeletal relationships, and improve, or prevent worsening of the vertical skeletal relationships. The results clearly showed improvement of the dental and AP skeletal relationships. The ANB and Wits appraisal decreased in the treated group; Class II correction was successful in 3 of the studies. Based on the mandibular plane angle, the vertical skeletal relations were generally maintained.

High-pull headgear treatment restricted the forward growth of the maxilla. Based on SNA changes, there was, on average, approximately 1.1 degree posterior repositioning of the maxilla in the treated subjects, compared to slight anterior repositioning for the untreated controls. Studies consistently report that headgears used to correct Class II malocclusions are generally effective in redirecting the maxillary growth posteriorly ${ }^{10,21,22}$ or in limiting the forward growth of the maxilla. ${ }^{23}$

High-pull headgear appears to produce a slight clockwise rotation of the palatal plane. However, this effect was small (less than 0.8 degrees on average) and inconsistent across studies of high-pull headgear. Other studies evaluating the effects of combined, cervical or high-pull headgear have also reported a 
lack of consistent results. ${ }^{10,23}$ Clockwise rotation of the palatal plane might be expected considering that the headgear forces are directly through the posterior maxilla, resulting in relatively greater inferior displacement of the anterior maxilla. If the force is applied in the canine area, high-pull headgear has been shown to decrease the palatal plane angle. ${ }^{24}$

Bowden $^{8,9}$ previously emphasized how important the point of force application was for understanding changes of the palatal plane angle. If the force vector passes through the center of resistance of the maxilla, which is approximately located at the superior and posterior part of the zygomatomaxillary suture, ${ }^{25,26}$ no moment will be created and no rotation should be expected. If however, the force vector pass posterior to the center of resistance, clockwise rotation of the maxilla might be expected. The direction and moment created will depend upon the shortest perpendicular distance from the force vector to the center of resistance.

Dentoalveolar changes were largely responsible for the correction of the Class II malocclusions. The maxillary molars were moved and tipped distally. Based on the averages derived from the studies, distal molar movement accounted for approximately $2.1 \mathrm{~mm}$ (between $84 \%$ and 100\%) of the correction. Headgears generally maintain or move the maxillary first molars distally. ${ }^{23,28}$ Vertically, high-pull headgear is used to control the vertical movements of the maxillary molars, and may even intrude them slightly, whereas cervical headgear has little or no effects on vertical molar changes. ${ }^{10,22-25}$

Although, on average, the maxillary incisors were retroclined and intruded, there was great variability (from -1.7 to $-4.5 \mathrm{~mm}$ in horizontal direction and from -2.1 to $0.2 \mathrm{~mm}$ in vertical direction) in the changes reported in the six studies evaluated. The literature is also inconsistent in terms of incisor changes for headgear studies in general. ${ }^{27}$ The variability could be attributed to differences in the force directions and study appliances used.

There were only very limited effects of the appliance on the mandible. Mandibular sagittal changes were effectively similar in the treated and untreated groups. Of the studies that evaluated the AP position of the mandible, all four reported no treatment effect.
As such, headgear improves the sagittal intermaxillary relationship almost exclusively by holding the maxilla. This effect on sagittal intermaxillary relationship is in contrast to functional appliances, which have shown improve sagittal intermaxillary relationship with treatment effects on the mandible. ${ }^{27,28}$ Slight clockwise rotation of the mandible occurred in only one study, indicating adequate vertical control. Compared with cervical headgear, the high-pull headgear therapy appears to provide better vertical control. ${ }^{29}$

With respect to mandibular tooth movements, the studies showed retroclination of the incisors. This can be explained by anterior contact of these teeth with the acrylic splint that covers the maxillary incisors, exerting a distal force on the incisors. When upper molars are intruded with the highpull headgear, the lower molar extruded might be expected in order to maintain occlusal contact. ${ }^{10,22}$ The lack of significant extrusion in the lower molars in the studies reviewed is associated with the maxillary splints that were used, acting like a bite block to maintain the position of the lower molars. Treatment had no effect on the mesial movements of the mandible molars.

\section{CONCLUSION}

While there is a lack of strong evidence demonstrating the effects of high-pull headgear with a splint, based on the information provided in this systematic review of four clinically controlled trials evaluating the effects of high-pull headgear on subjects with Class II malocclusions, the following conclusions could be drawn:

1. High-pull headgear displaced the maxilla posteriorly and slightly rotated the palatal plane clockwise.

2. The upper molars were distalized and the vertical position was maintained by highpull headgear. Treatment effects on the lower incisors were inconsistent.

3. High-pull headgear treatment consistently improved the AP skeletal relationships, but not the vertical skeletal relationships.

4. Greater attention to the design and report of studies should be given to improve the quality of such trials. 


\section{REFERENCES}

1. McNamara JA. Components of Class II malocclusion in children 8-10 years of age. Angle Orthod. 1981;51(3):177-202.

2. Proffit WR, Fields HW, Ackerman JL, Sinclair PM, Thomas PM, Tulloch JFC. Contemporary orthodontics. St. Louis: Mosby-Year Book; 1993.

3. Buschang PH, Sankey W, English JD. Early treatment of hyperdivergent open-bite malocclusions. Semin Orthod. 2002:8:130-40.

4. Isaacson JR, Isaacson RJ, Speidel TM, Worms FW. Extreme variation in vertical facial growth and associated variation in skeletal and dental relations. Angle Orthod. 1971;41(1):219-29.

5. Cangialosi T. Skeletal morphologic features of anterior open-bite. Am J Orthod. 1984;85(1):28-36.

6. Fields H, Proffit W, Nixon W, Phillips C, Stanek E. Facial pattern differences in long-faced children and adults. Am J Orthod. 1984;85(3):217-23.

7. Nanda S. Patterns of vertical growth in the face. Am J Orthod Dentofacial Orthop. 1988:93(2):103-16

8. Bowden DE. Theoretical considerations of headgear therapy: a literature review. Br J Orthod. 1978:5:145-52

9. Bowden DE. Theoretical considerations of headgear therapy: a literature review 2. Br J Orthod. 1978:5(4):173-81.

10. Brown P. A cephalometric evaluation of high-pull molar headgear and face-bow neck strap therapy. Am J Orthod. 1978;74(6):621-32.

11. Boecler PR, Riolo ML, Keeling SD, Tenhave TR. Skeletal changes associated with extraoral appliance therapy: an evaluation of 200 consecutively treated cases. Angle Orthod. 1989;59(4):263-70

12. Caldwell SF, Hymas TA, Timm TA. Maxillary traction splint: a cephalometric evaluation. Am J Orthod. 1984;85(5):376-84

13. Petrén S, Bondemark L, Soderfeld B. A systematic review concerning early orthodontic treatment of unilateral posterior crossbite. Angle Orthod. 2003;73(5):588-96.

14. Antczak AA, Tang J, Chalmers TC. Quality assessment of randomized control trials in dental research. I. Methods. J Periodontal Res. 1986:21:305-14.

15. Antczak AA, Tang J, Chalmers TC. Quality assessment of randomized control trials in dental research. II. Results: periodontal research. J Periodontal Res. 1986:21:315-21

16. Baumrind S, Korn EL, Isaacson RJ, West EE, Molthen R. Quantitative analysis of the orthodontic and orthopedic effects of maxillary traction. Am J Orthod. 1983:84(5):384-98.
17. Firouz M, Zernik J, Nanda R. Dental and orthopedic effects of high-pull headgear in treatment of Class II, division 1 malocclusion. Am J Orthod Dentofacial Orthop. 1992:102(3):197-205

18. Martins RP, Martins JCR, Martins LP, Buschang PH. Skeletal and dental components of Class II correction with the bionator and removable headgear splint appliances. Am J Orthod Dentofacial Orthop. 2008;134(6):732-41

19. Orton HS, Slattery DA, Orton S. The treatment of severe "gummy" Class I division 1 malocclusion using the maxillary intrusion splint. Eur J Orthod. 1992:14(3):216-23

20. Üner O, Ÿucel-Eroğlu E. Effects of a modified maxillary orthopaedic splint: a cephalometric evaluation. Eur J Orthod. 1996:18(3):269-86

21. Melsen B. Effects of cervical anchorage during and after treatment: an implant study. Am J Orthod. 1978;73(5):526-40.

22. Üçem TT, Yüksel S. Effects of different vectors of forces applied by combined headgear. Am J Orthod Dentofacial Orthop. 1998:113(3):316-23.

23. O'Reilly MT, Nanda SK, Close J. Cervical and oblique headgear: A comparison of treatment effects. Am J Orthod Dentofacial Orthop. 1993:103(6):504-9.

24. Barton JJ. High-pull headgear versus cervical traction: a cephalometric comparison. Am J Orthod. 1972:62(5):517-29.

25. Teuscher UM. A growth related concept for skeletal Class II treatment Am J Orthod. 1978:74(3):258-75

26. Teuscher UM. Appraisal of growth and reaction to extraoral anchorage. Am J Orthod. 1986:89(2):113-21

27. Keeling SD, Wheeler TT, King GJ, Garvan CW, Cohen DA, Cabassa S, et al. Anteroposterior skeletal and dental changes after early Class II treatment with bionators and headgear. Am J Orthod Dentofacial Orthop. 1998:113(1):40-50

28. Türkkahraman H, Sayin MÖ. Effects of activator and activator headgear treatment: comparison with untreated Class II subjects. Eur J Orthod. 2006:28(1):27-34

29. Burke M, Jacobson A. Vertical change in high angle Class II, division 1 patients treated with cervical or occipital headgear. Am J Orthod Dentofacial Orthop. 1992:102(6):501-8 